\title{
The Link between Corporate Social Responsibility and Financial Performance in the Hungarian Banking Sector in the Years Following the Global Crisis*
}

\author{
Nikolett Deutsch - Éva Pintér
}

The hectic economic changes in the past decade and the subsequent regulatory tightening have had a substantial negative impact on the operation of banking service providers. These providers have sought to arrest the decline in their profitability, to re-establish trust with their customers and to reinforce their competitive position with tools that presented banks as institutions which promote corporate social responsibility on the financial and capital markets, involving concepts such as responsible banking, green banking and ethical banking. However, the true extent of this rapid response focusing on corporate social responsibility and its effect on banks' long-term performance are difficult to measure. This study explores the assessment and measurement methodologies pertaining to the financial sector, and examines a sample of seven dominant market participants in the Hungarian banking sector to determine the relationship between banks' corporate social responsibility, its integration into operating activities and banks' financial performance in 2006-2013.

Journal of Economic Literature (JEL) codes: G00, G20, G21, G30

Keywords: corporate social performance (CSP), corporate financial performance (CFP), banking sector, Scholtens CSP

\section{Motivating forces behind corporate social responsibility in the banking sector}

The concept and practical implementation of corporate social responsibility (CSR) has been studied closely in recent decades, from both a theoretical and a practical perspective. The topic has also affected various areas and disciplines in economics.

\footnotetext{
* The papers in this issue contain the views of the authors which are not necessarily the same as the official views of the Magyar Nemzeti Bank.

Nikolett Deutsch is an Associate Professor at the Department of Strategy and Project Management in the Institute for the Development of Enterprises at the Business School of the Corvinus University of Budapest. E-mail: nikolett.deutsch@uni-corvinus.hu

Éva Pintér is an Associate Professor and Chartered Accountant in the Department of Finance and Accounting at the Faculty of Business and Economics of the University of Pécs. E-mail: pintereva@ktk.pte.hu
}

The paper was supported by the ÚNKP-17-4 New National Excellence Programme of the Ministry of Human Capacities.

The Hungarian manuscript was received on 6 February 2017.

DOI: http://doi.org/10.25201/FER.17.2.124145 
One only need think of the discussion on the orientation of value creation within organisations, which is mainly linked to strategic management, the renaissance of the stakeholder theory (e.g. Rappaport 2006; Porter-Kramer 2011; Ackermann Eden 2011), the focus on the "good management theory" (Brammer-Pavelin 2006), the approaches of sustainable development emphasising corporate social responsibility (Deutsch 2011), business ethics research on corporate social responsibility and accountability (Joyner - Payne 2002), social marketing (Kotler - Lee 2004), the business model innovation research increasingly popular in the innovation literature (Schaltegger et al. 2012) or the expanding toolset for assessing and managing organisations' CSR activities. When arguing for the promotion of CSR activities, the literature usually points to the strengthening of organisations' reputation and image (e.g. Marom 2006), rising customer loyalty and confidence (Mohr et al. 2001), the reduction of business risk and thus also the cost of capital (Bassen et al. 2006), the utilisation of the growth opportunities towards new products, services or markets (e.g. Sen - Bhattacharya 2001), and attracting and retaining skilled workers (Greening - Turban 2000). While CSR analyses and the research on the impact of corporate social performance (CSP) on corporate financial performance (CFP) usually focus on large production companies and service providers (Orlitzky 2011; Lu et al. 2014), the overwhelming majority of sectorspecific studies concentrate on the banking and financial sectors. In Hungary, many papers have been written with a focus on international comparison (e.g. Lentner et al. 2015), examining the regulatory tightening in the wake of the financial crisis (Borzán et al. 2011) and the responsibility of regulators and auditors (Lentner et al. 2010).

This is because in recent decades the rising significance of corporate social responsibility reports (Vigano - Nicolai 2009), the provision of responsible banking products (Scholtens 2008), the spread of sponsorship and donation activities and CSR spending (Truscott et al. 2009), i.e. the overall increase in CSR activities was observed in the banking sector. This is primarily a part of the response to the tightening of the regulations on banks' operation and the loss of confidence in the financial and capital markets attributable to the 2008 crisis, as the financial crisis highlighted banks' operational and regulatory shortcomings. Another consequence of this is that the Basel Committee required European banks to introduce the Basel III principles and ratios step by step in 2012-2019 to manage systemic risks. The paper by Härle et al. (2010) assumed a 1.5-4-per cent drop in European banks' profitability in the long run as a consequence of the implementation of the Basel capital requirements (raising the capital adequacy ratio to 9 per cent). Furthermore, during the crisis, banks also had to face the lack of confidence in financial institutions. They had to show that they act responsibly towards their customers, even at the social level, while also keeping an eye on the safety of depositors. In order to reinforce confidence and retain customers, banks published CSR reports to supplement and substantiate the implementation of regulatory requirements. 
Mcllroy (2008) argues that corporate social responsibility also protects banks from incorporating all risks into their financial products, and increases the transparency of the risks of financial products. The financial management of banks, just like other entities, aims to ensure profitability and profits. However, in the banking system this goal has to be achieved under special regulations on operating activities (Basel standards, the Hungarian Act CCXXXVII of 2013 on Credit Institutions and Financial Enterprises), while complying with three basic requirements, i.e. liquidity, solvency and prudent operation. This means that banks must generate returns while ensuring the safety of their customers in the long run, i.e. capital must provide adequate coverage for potential losses. Moreover, banks always have to hold enough funds to ensure smooth operation in the short run.

As regulation became increasingly rigorous, CSR has become a catchword among bankers, exerting a huge influence over society (Scholtens 2008). Its prominence was mainly motivated by the fact that from the perspective of banks' operating activities, risk and reputation are very important, which depend strongly on the perception by and relationship with customers (McDonald-Lai 2011). This relationship is built on trust, which must be strengthened (Flavian et al. 2005; Pérez et al. 2013). Improving stakeholder relations (Chomvilailuk - Butcher 2013) and perceptible environmental visibility can not only result in better reputation, but may also provide a competitive edge by reducing operating costs and risks (Yeung 2011), and it may also attract potential new investors and open up new markets (Tschopp 2012; Tran 2014). These motivating factors together imply that enhancing banks' social performance also exerts a positive effect on their financial results.

This paper examines the relationship between banks' financial and social performance. In order explore this, the study reviews the models used in the sectorindependent and bank-specific literature for measuring social performance (CSP) and financial performance (CFP) and the assessment of the link between the two performance indicators as well as the models' main conclusions. Then it turns to presenting the results of the regression analysis performed on a sample of seven banks operating as limited companies and controlling a dominant share of the Hungarian market in 2006-2013.

\section{Examination of the link between social and financial performance in the banking sector}

The analysis of corporate social responsibility and financial performance has been the subject of several empirical and normative studies in recent decades. However, as shown by the meta-analysis studies summarising the results of individual papers (e.g. Griffin - Mahon 1997; Orlitzky et al. 2003; Deckop et al. 2006; Beurden - Gössling 2008; Orlitzky 2011; Lu et al. 2014), the relevant literature does 
not provide a clear-cut answer regarding the nature of the relationship between social and financial performance, since there are examples of positive, negative and mixed links. In fact, some studies were unable to identify a significant connection between the two types of performance. Ruf et al. (2001), Brammer - Millington (2008) and Lee et al. (2009) argue that these conflicting results are attributable to both theoretical and methodological factors. The authors cite reasons such as the shortcomings of the theories on corporate social responsibility, the different considerations and methods of picking the factors determining social and financial performance, the lack of systematic, generally accepted methods for measuring social performance, the expectations regarding the CSP-CFP relationship based on different theories and methodological issues related to the examination of the CSP-CFP relationship.

Perhaps the greatest problem is that, as suggested by Griffin (2000), both CSP and CFP are so-called meta-constructs, and their definition is subject to a high degree of subjectivity, reflecting the different views of the individual authors and the theoretical approaches (stakeholder theory, institutional theory, neo-institutional theory) pursued by them. Despite the close attention devoted to CSR, there is still no generally accepted definition for it, or a consistent typology of the related activities and particulars. As a result, corporate social performance is measured using various methods. As the analysis of the studies on the CSP-CFP relationship reveals, Orlitzky et al. (2003), Deckop et al. (2006), Beurden and Gössling (2008), Orlitzky (2011) and Lu et al. (2014) all conclude that one of the most widely used methods for establishing social performance is based on the social and ethical ratings and reputation indices of the organisations under review. In the overwhelming majority of the papers, the CSP variable is calculated for the organisations under review based on the Dow Jones Sustainability Index, the FTSE4Good Index, the Ethibel Sustainability Index, the $\mathrm{KLD}^{1}{ }^{1}$ the $\mathrm{CRA},{ }^{2}$ the $\mathrm{CSRHub}^{3}$ or the Asset4esg ${ }^{4}$ indices. In a separate group of studies, CSP is determined based on the individual assessment or rating of the annual CSR or sustainability reports published by the organisations under review, where the CSP value is established using the distribution of economic value, CSR expenditure, environmental spending or sponsorship and donation outlays, or using a survey composed of unique factors. However, the use of the methodologies taking into account these different stakeholder groups, factors and indicators not only makes it difficult to compare the results and conclusions of the individual studies, but also entails the risk that the social performance of the organisations may be reflected in different, and even conflicting, values. In a similar but less complicated manner, corporate financial performance can be

${ }^{1}$ CSR index developed by KLD Research \& Analytics

${ }^{2}$ CSR index developed in line with the Community Reinvestment Act

${ }^{3}$ CSR rating developed by ACSRHub.com

${ }^{4}$ CSR index developed by Thomson Reuters 
measured using a variety of variables. There are approaches using market measures taking into consideration the effect exerted on companies' performance by market assumptions arising from CSR activities (e.g. Tobin's q, stock prices) and accounting indicators reflecting actual performance (e.g. ROA, ROE, EPS). In some studies, CFP is determined based on the results of the surveys conducted among the members of an organisation (Orlitzky et al. 2003; Deckop et al. 2006; Beurden - Gössling 2008; Orlitzky 2011; Lu et al. 2014).

Most authors examine the relationship between social and financial performance with a linear regression model, which can be geared towards the analysis of the effect of CSP on CFP or vice versa, but there are also regression systems taking into account the issue of a two-way impact (Deckop et al. 2006; Beurden - Gössling 2008; Orlitzky 2011; Lu et al. 2014). Yet ordinary linear regression models (OLS) are often criticised, on theoretical and practical claims that the CSP-CFP relationship is described much better by a curve than by a straight line (Barnett-Salomon 2006), and that the issue of endogeneity must be taken into account in examining the link between CSP and CFP, due to the so-called good management theory and the so-called resource slack theory (Waddock - Graves 1997; Schreck 2011). In the literature, the endogeneity attributable to simultaneity and the omitted variables are usually managed by two-step linear regression models and the Granger causality test (Schreck 2011; Lu et al. 2014). Of course, most regression models examining the CSP-CFP relationship also incorporate control variables. Based on the studies conducting meta-analysis (Orlitzky et al. 2003; Deckop et al. 2006; Beurden Gössling 2008; Orlitzky 2011; Lu et al. 2014), such control variables include firm size, the sector and its special features, the ownership structure, the capital structure, leverage, risk, R\&D intensity and advertising spending. Meanwhile, in the papers with an international comparison, control variables reflecting the local external environmental and macroeconomic factors, such as GDP growth, inflation or population size, are also used. The literature also cautions that when taking into account the special features of industries, companies, and national economies, CSP, CFP and the effects behind the relationship between them may appear through impact mechanisms and to extents that vary across sectors, companies and countries.

The assumptions and results of the examination of the link between corporate social responsibility and financial performance within the banking and the financial sector are also diverse. For measuring banks' CFP, the vast majority of the literature uses accounting indicators, such as return on equity (e.g. Soana 2011; Mozghovyi - Ratnykova 2011; Islam 2012; Marcia et al. 2013; Ofori et al. 2014), return on assets (e.g. Soana 2011; Mozghovyi - Ratnykova 2011; Ahmed et al. 2012; Islam 2012; Marcia et al. 2013; Jo et al. 2014; Ofori et al. 2014), net profits (e.g. Mozghovyi - Ratnykova 2011; Okwemba et al. 2014; Malik - Nadeem 2014), net interest income ( $W u$ - Shen 2013) or the NPL ratio ( $W u$ - Shen 2013; 
Simpson - Kohers 2002), and there are also examples for using market indicators (Saxena - Kohli 2012; Carnevale - Mazzuca 2014; Ahmed et al. 2012). Major differences can be seen with respect to measuring banks' social performance. As it has already been suggested in connection with the general CSP-CFP research, even in the case of these sector-specific assessments, one frequent method of gauging social performance is to use the CSR or ethical indices published by rating agencies (e.g. KLD, CRA, ESI, ${ }^{5}$ EIRIS, ${ }^{6}$ Asset4esg) (Simpson - Kohers 2002; Soana 2011; Saxena - Kohli 2012). Nevertheless, many studies attempt to develop their own CSP indicators (Pérez et al. 2013; Wu - Shen 2013; Mallin et al. 2014), examine CSR reports (Rogošić 2014; Okwemba et al. 2014), measure environmental and CSR spending (Mozghovyi - Ratnykova 2011; Okwemba et al. 2014; Omoro et al. 2014; Jo et al. 2014), or determine the performance based on a survey conducted among customers or an organisation's members (Islam 2012; Ahmed et al. 2012; Raihan et al. 2015; Malik - Nadeem 2014; Ofori et al. 2014; Fatma et al. 2014). Among the CSP measurement practices, the framework that deserves special mention was developed by Scholtens (2008) in order to eliminate the shortcomings of ethical and CSR indices and surveys and the lack of consistency among them (attributable to the use of different factors, stakeholder groups and indicators), specifically geared towards measuring banks' social performance in a transparent manner. The use of Scholtens's framework can be increasingly observed in studies (see Relano - Paulet 2012; Laidroo - Sokolova 2015), mainly because this method enables the uniform comparison of the social performance of banks that are not included in CSR or ethical rating databases, since in such cases CSP is determined based on publicly available bank data. As shown in Table 1, Scholtens's CSP indicator consists of 5 criteria and 32 indicators in total, taking into account the international recommendations and principles pertaining to the assessment of banks' and financial organisations' CSR activities. However, one of its drawbacks is that its assessment criteria are difficult to reconcile with the social, environmental, employee, community, governance or economic categories of CSR indices and ratings. Moreover, the evaluation of the indicators with 0 or 1 is unable to capture the slight differences between banks' performance, or extra performance within the individual categories.

\footnotetext{
${ }^{5}$ Environmental Sustainability Index

${ }^{6}$ The CSR index developed by EIRIS (Ethical Investment Research Services)
} 


\section{Table 1}

\section{Scholtens's framework for measuring banks' social performance}

\begin{tabular}{|c|c|c|}
\hline Main indicators & Sub-criteria & Description \\
\hline \multirow{6}{*}{$\begin{array}{l}\text { I. Business ethics, } \\
\text { sustainability reports }\end{array}$} & 1. Sustainability report & 0: Does not have a CSR report, 1: Has a CSR report \\
\hline & $\begin{array}{l}\text { 2. Supporting ICC Business Charter for Sustainable } \\
\text { Development }\end{array}$ & 0: Not an ICC signatory, 1: ICC signatory \\
\hline & 3. UNEP FI & 0: Not adopted, 1: Adopted \\
\hline & 4. Equator Principles & 0: Not adopted, 1: Adopted \\
\hline & 5. Global Compact & 0: Not adopted, 1: Adopted \\
\hline & 6. "Who Cares Wins" & $\begin{array}{l}\text { 0: Did not participate in the programme, } 1 \text { : } \\
\text { Participated in the programme }\end{array}$ \\
\hline \multirow{10}{*}{$\begin{array}{l}\text { II. Environmental } \\
\text { management }\end{array}$} & 7. Environmental management system (EMAS) & 0: No, 1: Yes \\
\hline & 8. Environmental management system (ISO14001) & 0: No, 1: Yes \\
\hline & 9. Environmental policy & 0: No, 1: Yes \\
\hline & 10. Taking into account the supply chain & 0: No, 1: Yes \\
\hline & 11. Quantification of environmental targets & $\begin{array}{l}\text { 0: No quantified targets are defined } \\
\text { 1: Quantified targets are defined }\end{array}$ \\
\hline & 12. Transparency of environmental targets & 0: No transparent targets, 1 : Transparent targets \\
\hline & $\begin{array}{l}\text { 13. Taking into account environmental risks when } \\
\text { lending }\end{array}$ & 0: No, 1: Yes \\
\hline & 14. Exclusion of special sectors & 0: No, 1: Yes \\
\hline & $\begin{array}{l}\text { 15. Taking into account World Bank guidelines on } \\
\text { managing environmental risks }\end{array}$ & 0: No, 1: Yes \\
\hline & $\begin{array}{l}\text { 16. Taking into account OESO guidelines on } \\
\text { managing environmental risks }\end{array}$ & 0: No, 1: Yes \\
\hline \multirow{7}{*}{$\begin{array}{l}\text { III. Responsible } \\
\text { financial products }\end{array}$} & 17. Socially responsible investments & 0: No, 1: Yes \\
\hline & 18. Socially responsible savings & 0: No, 1: Yes \\
\hline & 19. Sustainable financing & 0: No, 1: Yes \\
\hline & 20. Microcredit & 0: No, 1: Yes \\
\hline & 21. Environmental advice services & 0: No, 1: Yes \\
\hline & 22. Climate products & 0: No, 1: Yes \\
\hline & 23. Other sustainability products & 0: No, 1: Yes \\
\hline \multirow[t]{6}{*}{ IV. Social conduct } & 24. Sponsorship & 0: No, 1: Yes \\
\hline & 25. Community involvement & 0: No, 1: Yes \\
\hline & 26. Training and education & 0: No, 1: Yes \\
\hline & 27. Diversity and opportunities & 0: No, 1: Yes \\
\hline & 28. Feedback from employees & 0: No, 1: Yes \\
\hline & 29. Business ethics & 0: No, 1: Yes \\
\hline \multirow[t]{4}{*}{ V. Benchmarking } & 30. Dow Jones Sustainability Index & $0:$ Not in it, $1: \ln$ it \\
\hline & 31. FTSE4Good & 0 : Not in it, 1 : In it \\
\hline & 32. Domini Social Index & $0:$ Not in it, 1 : In it \\
\hline & 33. ESI Europe & $0:$ Not in it, $1: \ln$ it \\
\hline
\end{tabular}

Source: Based on Scholtens (2008: 165) 
With respect to the methodology used in the sources focusing on the banking sector, it can be seen that-similar to non-sector-specific analyses - the CFP-CSP relationship is usually evaluated using correlation analysis or linear regression analysis. Only a handful of papers (Wu - Schen 2013; Mallin et al. 2014; Jo et al. 2014) strive to take into account the issue of endogeneity. In the case of bank CSP-CFP analyses, the most frequent control variables in regression models are firm size, the time elapsed since the establishment of the organisation and the ownership structure indicators, however, there are also examples for CAMELS-based capital adequacy, asset quality, coverage and liquidity indicators taking into account banks' special performance characteristics (Simpson - Kohers 2002; Wu - Schen 2013; Mallin et al. 2014; Jo et al. 2014). The capital adequacy ratio reflects the basic requirement for solvent and efficient banking operation, i.e. the efficient management of capital, since in the long run, equity guarantees a bank's solvency and the correction of potential adverse events. Asset quality shows the recovery risk of receivables, i.e. outstanding amounts, against customers, credit institutions and other external parties, which make up the largest share of a bank's assets. Management efficiency, i.e. the indicator derived from the quotient of administrative expenses and total assets, takes into account the activities related to management, i.e. the resolution of internal conflicts of interest, the visibility and accountability of the organisation, the bank's increasing efficiency and the reduction of operational risks, while liquid banks are able to meet all claims against them at any time with an adequate amount of liquid assets.

With regard to the impact of banks' CSP on CFP, all in all it can be stated that while some studies (Bolton 2012; Simpson - Kohers 2002; Mallin et al. 2014; $W u$-Shen 2013; Islam 2012; Marcia et al. 2013) have uncovered a positive effect or were unable to identify a clear-cut link between the two (e.g. Das et al. 2015; Soana 2011; Mozghovyi - Ratnykova 2011; Ahmed et al. 2012; Raihan et al. 2015; Malik - Nadeem 2014), no paper on banks under review has confirmed a negative relationship between banks' social and financial performance. Therefore, overall it can be asserted that bank-specific CSP-CFP assessments rely heavily on nonsector-specific analyses with respect to determining the performance indicators, the methodology used and the variables taken into account during the analysis, and they also seek to incorporate the sector's special features.

\section{Relationship between social and financial performance based on a sample of seven Hungarian banks}

In view of the findings of the previous chapter, the present analysis attempts to establish the relationship between social and financial performance in the case of seven banks ${ }^{7}$ with a dominant market share in the Hungarian banking sector

\footnotetext{
${ }^{7}$ Budapest Bank, CIB Bank, Erste Bank, Kereskedelmi és Hitelbank, MKB Bank, OTP Bank and Raiffeisen Bank
} 
between 2006 and 2013 and operating in the form of a limited company according to the classification of the Magyar Nemzeti Bank acting in the capacity of supervisor. In addition to the same form of operation, the choice of these seven banks is also justified by the fact that they were present with a dominant market share on the Hungarian market during the whole period under review, and public information is available on their past CSR activities. In total, there were 56 bank years during the period under review. The relationship between banks' social and financial performance was examined using regression analysis and a two-step linear regression analysis for the whole sample, with the help of the SPSS 22.0 statistical analysis software. Based on the literature describing the link between banks' social and financial performance, the main elements of the regression models describing the relationship between financial and social performance are summarised in Table 2.

\begin{tabular}{|c|c|c|}
\hline \multicolumn{3}{|c|}{$\begin{array}{l}\text { Table } 2 \\
\text { Variables of the regression model and the two-step linear regression model }\end{array}$} \\
\hline Variable name & Measurement of the variable & Data source \\
\hline \multicolumn{3}{|l|}{ Dependent variable(s) } \\
\hline $\mathrm{NI}$ & Net profits & Annual report \\
\hline AROE & After-tax income/Average equity & Annual report \\
\hline AROA & After-tax income/Average assets & Annual report \\
\hline \multicolumn{3}{|l|}{ Independent variables } \\
\hline CSP1 & $\begin{array}{l}\text { Scholtens bank social performance } \\
\text { indicator }\end{array}$ & $\begin{array}{l}\text { CSR reports, banks' } \\
\text { websites }\end{array}$ \\
\hline CSP2 & $\begin{array}{l}\text { Modified Scholtens bank social } \\
\text { performance indicator }\end{array}$ & $\begin{array}{l}\text { CSR reports, banks' } \\
\text { websites }\end{array}$ \\
\hline \multicolumn{3}{|l|}{ Control variables } \\
\hline Capital adequacy (CA) & Equity/Total assets & Annual report \\
\hline Asset quality (AQ) & Risk provision and impairment/Equity & Annual report \\
\hline Management efficiency (ME) & Overhead expenses/Total assets & Annual report \\
\hline Liquidity coverage (LC) & $\begin{array}{l}\text { Debt/(Deposits + Short-term self-issued } \\
\text { funds) }\end{array}$ & Annual report \\
\hline Liquidity (LI) & (Cash + Monetary funds)/Total assets & Annual report \\
\hline Size (FS) & Natural logarithm of total assets & Annual report \\
\hline
\end{tabular}

It can be seen from Table 2 that in this paper's regression models financial performance interpreted as a dependent variable was expressed with accounting indicators, more specifically the average return on equity (AROE) and the average return on assets (AROA). Using net income as a dependent variable was considered important because as Barnett and Salomon (2012: 1309) caution, the use of 
dependent variables expressed as ratios may lead to distorted results or more complicated relationships, since in this case the independent variables may affect the numerator, the denominator or both.

In the absence of the CSR indices determined by rating agencies, banks' social performance was measured relying on Scholtens's (2008) framework in two ways. First, based on Laidroo and Sokolova (2015), banks' average annual performance was determined using 29 indicators from Scholtens's framework (CSP1). Then the social performance of each bank was determined again, based on modified criteria of Scholtens's model (CSP2). In the modified Scholtens model (Table 3), the main and sub-criteria of the baseline model were modified to resolve earlier shortcomings (related to applying employee concerns, the examination of the strategic and organisational incorporation of CSR and the separation of direct and indirect social engagement), and we also sought to omit the variables that were in the original model but were less relevant from the perspective of Hungarian banks, or that could not be taken into account due to a lack of data. Both social performance indicators were calculated based on information in the annual accounts of the banks, or, in certain cases, their parent companies, their own CSR or sustainability reports or websites, for all the years in the period under review, by calculating the average (Table 4). 


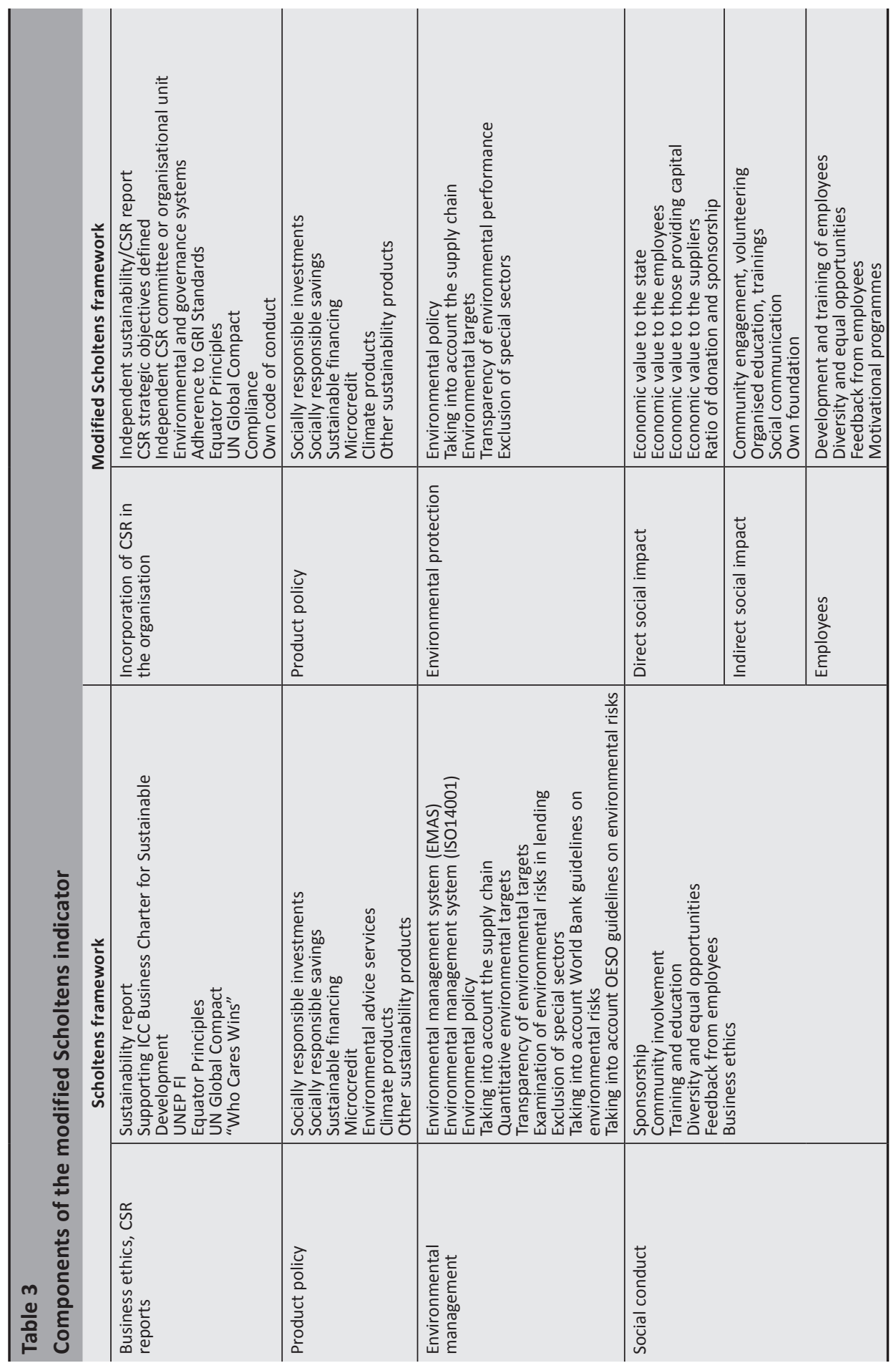


Based on the sector-specific studies, the control variables of the regression models were chosen from the elements of the CAMELS model used for analysing credit institutions' performance, while the impact of firm size was measured with the firm size (FS) indicator expressed as the natural logarithm of total assets. The values of the financial performance indicators and the control variables were determined based on banks' annual accounts and the MNB's Golden Books.

\begin{tabular}{|c|c|c|c|c|c|c|c|c|c|c|c|c|c|c|c|c|}
\hline \multicolumn{17}{|c|}{$\begin{array}{l}\text { Tabl } \\
\text { CSP } \\
(\%)\end{array}$} \\
\hline & \multicolumn{8}{|c|}{ CSP1 } & \multicolumn{8}{|c|}{ CSP2 } \\
\hline & 2006 & 2007 & 2008 & 2009 & 2010 & 2011 & 2012 & 2013 & 2006 & 2007 & 2008 & 2009 & 2010 & 2011 & 2012 & 2013 \\
\hline 1 & 16.67 & 20.24 & 23.81 & 23.81 & 27.98 & 32.14 & 32.14 & 27.98 & 14.64 & 21.38 & 24.91 & 24.19 & 37.15 & 41.39 & 41.63 & 32.58 \\
\hline 2 & 31.67 & 31.67 & 50.48 & 59.64 & 62.14 & 62.14 & 62.14 & 62.14 & 45.71 & 47.17 & 63.89 & 67.62 & 67.74 & 69.36 & 69.43 & 69.44 \\
\hline 3 & 25.00 & 25.00 & 25.00 & 20.83 & 28.57 & 28.57 & 36.07 & 36.07 & 9.95 & 18.09 & 19.61 & 21.95 & 28.99 & 28.99 & 38.99 & 39.01 \\
\hline 4 & 47.98 & 47.98 & 55.48 & 55.48 & 64.64 & 68.21 & 68.21 & 68.21 & 45.88 & 50.76 & 63.43 & 61.67 & 73.73 & 75.56 & 75.95 & 75.86 \\
\hline 5 & 8.33 & 8.33 & 43.81 & 43.81 & 46.31 & 46.31 & 32.14 & 32.14 & 18.47 & 13.86 & 56.66 & 59.09 & 62.86 & 62.87 & 40.42 & 40.34 \\
\hline 6 & 47.38 & 47.38 & 49.88 & 53.45 & 53.45 & 53.45 & 53.45 & 53.45 & 38.99 & 62.43 & 66.91 & 67.98 & 68.31 & 68.28 & 68.29 & 68.47 \\
\hline 7 & 16.67 & 16.67 & 32.50 & 32.50 & 32.50 & 32.50 & 31.07 & 31.07 & 9.83 & 13.84 & 38.49 & 36.82 & 36.99 & 28.98 & 28.96 & 32.38 \\
\hline
\end{tabular}

Based on the regression tests performed for the data under review, the relationship between the dependent and the independent variables can be best described using a linear regression equation, which takes the following general form based on the variables under examination (see Table 2):

$$
\mathrm{CFP}_{\mathrm{i}}=\beta_{1} \mathrm{CSP}_{\mathrm{i}}+\beta_{2} \mathrm{CA}_{\mathrm{i}}+\beta_{3} \mathrm{AQ}_{\mathrm{i}}+\beta_{4} \mathrm{ME}_{\mathrm{i}}+\beta_{5} \mathrm{LC}_{\mathrm{i}}+\beta_{6} \mathrm{LI}_{\mathrm{i}}+\beta_{7} \mathrm{FS}_{\mathrm{i}}+\varepsilon
$$

Table 5 summarises the results of the robust linear regression analyses with respect to net income, average return on equity and average return on assets for the individual social performance indicators. During the regressions, White's robust standard errors were applied. It can be seen from the table that when using the Scholtens social performance indicator (CSP1), the values of the multiple correlation coefficient $\left(r_{\mathrm{NI}}=0.803, \mathrm{r}_{\mathrm{AROE}}=0.732, \mathrm{r}_{\mathrm{AROA}}=0.748\right)$ show that there is a moderate or strong linear correlation between the dependent and independent variables. Based on the values of the multiple determination coefficients $\left(R^{2}\right), 64.5$ per cent of the dispersion of net income can be explained by the changes in independent variables, and the same holds true for 58.7 per cent of the average return on equity and 60.8 per cent of the average return on assets. Similar values can be seen when applying the modified Scholtens social performance indicator (CSP2), however, it must be borne in mind that in these models, the strength of the linear correlation between the dependent and the independent variables increases, and 
the explanatory power of independent variables is also greater. Nonetheless, it also should be mentioned that the changes in all dependent variables are influenced by other factors not included in this analysis, and the examination should also be conducted for a longer time interval.

\section{Table 5}

Summary table of linear regression models - With dependent variables of NI, AROE and AROA, and independent variables of CSP1 and CSP2

\begin{tabular}{l|c|c|c|c|c|c}
\multirow{2}{*}{} & \multicolumn{3}{|c|}{ With CSP1 } & \multicolumn{3}{c}{ With CSP2 } \\
\cline { 2 - 7 } & NI & AROE & AROA & NI & AROE & AROA \\
\hline $\mathrm{R}$ & 0.803 & 0.732 & 0.748 & 0.813 & 0.751 & 0.762 \\
\hline $\mathrm{R}^{2}$ & 0.645 & 0.587 & 0.608 & 0.660 & 0.589 & 0.617 \\
\hline Adjusted R Square & 0.593 & 0.526 & 0.551 & 0.611 & 0.529 & 0.561 \\
\hline
\end{tabular}

Examining the impact of the regression coefficients on financial performance (Table 6) shows that the negative effect of social performance (CSP1 and CSP2), asset quality (AQ) and liquidity coverage (LC) on net income has been confirmed, and so has the positive effect of firm size (FS) on it, while the effect of management efficiency (ME) and liquidity (LI) cannot be validated. In the case of the modified Scholtens indicator, capital adequacy (CA) has a slight positive effect on net income. With respect to the average return on equity (AROE), asset quality was confirmed to have a significantly negative impact in both linear regression models, while liquidity coverage had a moderate impact. The negative effect of social performance on ROE can only be proven in the regression model containing the modified Scholtens indicator (CSP2). When using the average return on assets, the negative effect of asset quality as a control variable was validated. Nevertheless, while the negative impact of social performance could not be shown with using the Scholtens indicator (CSP1), when the modified Scholtens indicator (CSP2) was applied, it was proven that social performance reduces the return on assets. 


\begin{tabular}{|c|c|c|c|}
\hline \multicolumn{4}{|c|}{$\begin{array}{l}\text { Table } 6 \\
\text { Coefficients taking into } \\
\text { CSP2 - With all factors }\end{array}$} \\
\hline \multirow{2}{*}{$\begin{array}{l}\text { Independent } \\
\text { variables }\end{array}$} & \multicolumn{3}{|c|}{ Dependent variables } \\
\hline & Net profits & AROE & AROA \\
\hline \multicolumn{4}{|c|}{ With the Scholtens social performance } \\
\hline $\begin{array}{l}\text { Constant } \\
\text { (Std. Error) }\end{array}$ & $\begin{array}{c}-484,603 * * \\
(192,894)\end{array}$ & $\begin{array}{c}2.73451 \\
(1.99880)\end{array}$ & $\begin{array}{c}0.0717541 \\
(0.0971166)\end{array}$ \\
\hline CSP1 & $\begin{array}{c}-86,006.1^{*} \\
(45,397.8)\end{array}$ & $\begin{array}{c}-0.1016 \\
(0.326682)\end{array}$ & $\begin{array}{l}-0.0288578 \\
(0.0206855)\end{array}$ \\
\hline CA & $\begin{array}{c}265,948 \\
(184,011)\end{array}$ & $\begin{array}{c}-1.47886 \\
(0.962617)\end{array}$ & $\begin{array}{l}0.00942178 \\
(0.0690040)\end{array}$ \\
\hline$A Q$ & $\begin{array}{c}-38,128.5 * * * \\
(7,622.84)\end{array}$ & $\begin{array}{c}-0.417082^{* * *} \\
(0.0641854)\end{array}$ & $\begin{array}{c}-0.0218310 * * * \\
(0.00305243)\end{array}$ \\
\hline ME & $\begin{array}{c}399,423 \\
(435,347)\end{array}$ & $\begin{array}{l}0.467713 \\
(2.05843)\end{array}$ & $\begin{array}{l}0.0462294 \\
(0.149819)\end{array}$ \\
\hline LC & $\begin{array}{c}-48,543.3^{* *} \\
(20,416)\end{array}$ & $\begin{array}{c}-0.393224^{*} \\
(0.211651)\end{array}$ & $\begin{array}{c}-0.0240745^{* *} \\
(0.0105019)\end{array}$ \\
\hline LI & $\begin{array}{c}8,355 \\
(8,485.57)\end{array}$ & $\begin{array}{c}0.0501049 \\
(0.0587081)\end{array}$ & $\begin{array}{c}0.00362491 \\
(0.00349325)\end{array}$ \\
\hline FS & $\begin{array}{c}39,421.1 * * * \\
(12,581.7)\end{array}$ & $\begin{array}{l}-0.123892 \\
(0.121207)\end{array}$ & $\begin{array}{l}-0.00107046 \\
(0.00610950)\end{array}$ \\
\hline \multicolumn{4}{|c|}{ With the modified Scholtens social performance } \\
\hline $\begin{array}{l}\text { Constant } \\
\text { (Std. Error) }\end{array}$ & $\begin{array}{c}-536,127 * * \\
(202,106)\end{array}$ & $\begin{array}{c}2.55206 \\
(2.10045)\end{array}$ & $\begin{array}{l}0.0564608 \\
(0.101774)\end{array}$ \\
\hline CSP2 & $\begin{array}{c}-89,941.2^{* *} \\
(42,230.7)\end{array}$ & $\begin{array}{c}-0.159699 * \\
(0.311049)\end{array}$ & $\begin{array}{c}-0.0293010^{*} \\
(0.0184572)\end{array}$ \\
\hline$C A$ & $\begin{array}{l}357,614^{*} \\
(203,101)\end{array}$ & $\begin{array}{l}-1.30930 \\
(1.12531)\end{array}$ & $\begin{array}{c}0.0391734 \\
(0.0775070)\end{array}$ \\
\hline$A Q$ & $\begin{array}{c}-36,623.2^{* * * *} \\
(7,695.08)\end{array}$ & $\begin{array}{c}-0.414654 * * * \\
(0.0666511) \\
\end{array}$ & $\begin{array}{c}-0.0214430 * * * \\
(0.00313394)\end{array}$ \\
\hline ME & $\begin{array}{c}296,506 \\
(417,520) \\
\end{array}$ & $\begin{array}{c}0.30629 \\
(1.88541)\end{array}$ & $\begin{array}{l}0.0123526 \\
(0.146053)\end{array}$ \\
\hline LC & $\begin{array}{c}-48,394.7^{* *} \\
(20,706.5)\end{array}$ & $\begin{array}{c}-0.395319 * \\
(0.213633)\end{array}$ & $\begin{array}{c}-0.0239875^{* *} \\
(0.015357)\end{array}$ \\
\hline LI & $\begin{array}{c}7,425.28 \\
(7,800.60)\end{array}$ & $\begin{array}{l}-0.0485320 \\
(0.0565713)\end{array}$ & $\begin{array}{c}0.00332075 \\
(0.00328560)\end{array}$ \\
\hline FS & $\begin{array}{c}43,192.2 * * * \\
(13,174.2)\end{array}$ & $\begin{array}{l}-0.109529 \\
(0.128009)\end{array}$ & $\begin{array}{l}3.23360 \mathrm{e}-05 \\
(0.00640038)\end{array}$ \\
\hline
\end{tabular}




\begin{tabular}{|c|c|c|c|}
\hline \multicolumn{4}{|c|}{$\begin{array}{l}\text { Coefficients taking into account the Scholtens CSP1 and the modified Scholtens } \\
\text { CSP2 - With significant factors }\end{array}$} \\
\hline \multirow{2}{*}{$\begin{array}{l}\text { Independent } \\
\text { variables }\end{array}$} & \multicolumn{3}{|c|}{ Dependent variables } \\
\hline & Net profits & AROE & AROA \\
\hline \multicolumn{4}{|c|}{ With the Scholtens social performance } \\
\hline $\begin{array}{l}\text { Constant } \\
\text { (Std. Error) }\end{array}$ & $\begin{array}{l}-352,759 * * \\
(168,385)\end{array}$ & $\begin{array}{l}0.558785 * * * \\
(0.179271)\end{array}$ & $\begin{array}{l}0.0436536 * * * \\
(0.00932544)\end{array}$ \\
\hline CSP1 & $\begin{array}{l}-81,116.1 * \\
(43,428.7)\end{array}$ & & \\
\hline$A Q$ & $\begin{array}{l}-43,821.6 * * * \\
(6,101.28)\end{array}$ & $\begin{array}{l}-0.377446 * * * \\
(0.0542081)\end{array}$ & $\begin{array}{l}-0.0217175^{* * *} * \\
(0.00250649)\end{array}$ \\
\hline LC & $\begin{array}{c}-72,160.0 * * * \\
(19,279.7)\end{array}$ & $\begin{array}{c}-0.237039 * \\
(0.141556)\end{array}$ & $\begin{array}{c}-0.0202774 * * * \\
(0.00731349)\end{array}$ \\
\hline FS & $\begin{array}{c}35,589.8 * * * \\
(11,864.8)\end{array}$ & & \\
\hline \multicolumn{4}{|c|}{ With the modified Scholtens social performance } \\
\hline $\begin{array}{l}\text { Constant } \\
\text { (Std. Error) }\end{array}$ & $\begin{array}{c}-509,119 * * \\
(190,964)\end{array}$ & $\begin{array}{c}0.558785 * * * \\
(0.179271)\end{array}$ & $\begin{array}{c}0.0436536 * * * \\
(0.00932544)\end{array}$ \\
\hline CSP2 & $\begin{array}{c}-91,766.0 * * \\
(41,635.2)\end{array}$ & $\begin{array}{c}-0.11977425^{*} \\
(0.23926846)\end{array}$ & $\begin{array}{c}-0.02197575^{*} \\
(0.0184572)\end{array}$ \\
\hline $\mathrm{CA}$ & $\begin{array}{l}425,051 * * \\
(161,974)\end{array}$ & & \\
\hline$A Q$ & $\begin{array}{c}-35,919.3^{* * * *} \\
(7,181.52)\end{array}$ & $\begin{array}{c}-0.377446 * * * \\
(0.0542081) \\
\end{array}$ & $\begin{array}{c}-0.0217175^{* * *} * \\
(0.00250649)\end{array}$ \\
\hline LC & $\begin{array}{c}-51,052.0 * * * \\
(18,155.9)\end{array}$ & $\begin{array}{c}-0.237039 * \\
(0.141556)\end{array}$ & $\begin{array}{c}-0.0202774 * * * \\
(0.00731349)\end{array}$ \\
\hline FS & $\begin{array}{c}42,288.4 * * * \\
(12,850.9)\end{array}$ & & \\
\hline
\end{tabular}

Since there appeared to be no significant link to most of the explanatory variables in the original regression results (Table 6), when running another round of robust regression analysis, only significant factors were applied as explanatory variables (Table 7). As there is no relevant difference in terms of magnitude between the results of the original regression and the one with the omitted variables with respect to the impact of independent variables, it can be stated that there is no substantial correlation (multicollinearity) between the significant variables and the parameters left out of the second regression, therefore our estimate is not distorted (Rádóczy 2017).

With respect to net income, the analyses with both social indicators confirmed the results of the linear regression analyses performed with all the factors. With the Scholtens indicator, the negative impact of liquidity coverage on net income became 
stronger, while in the case of the modified Scholtens indicator, the positive effect of capital adequacy and the negative effect of liquidity coverage on net income could be confirmed. With respect to the average return on equity, a negative relationship could be shown even in a robust regression analysis with significant factors between financial performance interpreted as the average return on equity and asset quality as well as liquidity coverage. Moreover, it was proven that social performance as expressed in CSP2 influences AROE negatively. With regard to the average return on assets, the negative relationship between corporate social responsibility as expressed in CSP2 and ROA was confirmed, just like the significantly negative impact of asset quality and liquidity coverage taken into account as control variables.

\section{Main conclusions}

In the past decade, economic and sectoral changes and new impact mechanisms led to new competition and realignment in the Hungarian banking sector. As the most important consequence, policies and ratios aimed at safe capital adequacy and defined by the Basel Committee (and Hungarian accounting rules) have appeared that have applied to Hungarian banks since January 2008. In the Basel III regulation, the concept of leverage was modified, the countercyclical capital buffer was introduced and capital calculation became stricter (Tier 1 capital ratio ${ }^{8}$ ). As a result of the introduction of the capital buffer, the required level of the capital adequacy ratio will be raised in the long run. The European Banking Authority expects systemically important financial institutions to have a capital adequacy ratio of 9 per cent since June 2012. The risk management methods and policies are supplemented by the provision for the liabilities linked to lending. This provision and the credit coverage capacity of equity play a significant practical role because the MNB's Funding for Growth Scheme launched in 2013 boosted banks' credit. Thus asset quality indicates the recovery risk of receivables, because the NPL ratio has increased considerably in the banking sector since the onset of the financial crisis, and only a moderate fall in its value can be observed.

Although our study does not cover the whole Hungarian banking sector and contradicts the results of papers on international banking, it clearly proves that on the part of the major players in the Hungarian banking system, the subsidised loans and microcredit that appeared in their product policies and their sponsorship and educational engagement as well as a wide range of corporate social responsibility activities in foundations were responses to the consequences of the global financial crisis of the past decade and the loss of market share. This had a negative impact on income, return on equity and return on asset indicators, while banks focused on retaining customers and complying with stringent regulatory limits. Although

\footnotetext{
${ }^{8}$ Tier 1 capital ratio = Equity capital / Risk-weighted assets

Capital adequacy ratio $=$ Own funds $/$ Risk-weighted assets
} 
these factors resulted in negative returns in the present short-term analysis, they may provide returns in the long run, since it was confirmed that capital adequacy is positively correlated with net income. Granted, this implies that capital adequacy can be maintained in the long run, while the banking system achieves greater profitability in the context of a growing and higher-quality loan portfolio and better risk management. In the short run, the return on equity is clearly negatively influenced by the higher provisions required by regulatory limits, the reclassification or restructuring and better risk management of the loan portfolio resulting in improved asset quality as well as the effectiveness of the Funding for Growth Scheme that improved liquidity coverage. Unfortunately, the latter seems to be even more effective on account of lower deposit taking due to the rise in alternative investment products (e.g. unit linked products). The two last factors also exert a negative impact on the return on assets, and although social responsibility and performance also influence the ROA negatively in the short run, they help restore the trust that disappeared from the bank-customer relationship during the crisis. In the long run, the customer base, resting on a safer and better risk management footing, will be the factor that facilitates banks' survival, competitiveness on the market and increasing profitability.

\section{References}

Ackermann, F. - Eden, C. (2011): Strategic Management of Stakeholders: Theory and Practice, Long Range Planning, 44(3): 179-196. https://doi.org/10.1016/j.Irp.2010.08.001

Ahmed, S.U. - Islam, Z. - Hasan, I. (2012): Corporate social responsibility and financial performance linkage. Journal of Organizational Management, 1(1): 14-21.

Barnett, M.L. - Salomon, R.M. (2006): Beyond dichotomy: The curvilinear relationship between social responsibility and financial performance. Strategic Management Journal, 27(11): 1101-1122. https://doi.org/10.1002/smj.557

Barnett, M.L. - Salomon, R.M. (2012): Does it pay to be really good? Addressing the shape of the relationship between social and financial performance. Strategic Management Journal, 33(11): 1304-1320. https://doi.org/10.1002/smj.1980

Bassen, A. - Meyer, K. - Schlange, J. (2006): The influence of corporate responsibility on the cost of capital. https://doi.org/10.2139/ssrn.984406

Beurden, van, P. - Gössling, T. (2008): The Worth of Values - A Literature Review on the Relation Between Corporate Social and Financial Performance. Journal of Business Ethics, 82(2): 407-424. https://doi.org/10.1007/s10551-008-9894-x

Bolton, B. (2012). Corporate Social Responsibility and Bank Performance. https://papers. ssrn.com/sol3/papers.cfm?abstract_id=2277912. Accessed: 20 June 2015 
Borzán, A. - Lentner, Cs. - Szigeti, C. (2011): Pénzügyi vállalkozások felelösségvállalásának új dimenziói (New dimensions of the social responsibility of financial enterprises). Economica, 4(11): 22-30.

Brammer, S. - Millington, A. (2008): Does it pay to be different? An analysis of the relationship between corporate social and financial performance. Strategic Management Journal, 29(12): 1325-1343. https://doi.org/10.1002/smj.714

Brammer, S. - Pavelin, S. (2006): Corporate reputation and social performance: the importance of fit. Journal of Management Studies, 43 (3): 436-456. https://doi.org/ 10.1111/j.1467-6486.2006.00597.x

Carnevale, C. - Mazzuca, M. (2014): Sustainability report and bank valuation: evidence from European stock markets. Business Ethics: A European Review, 23(1): 69-90. https://doi.org/ 10.1111/beer.12038

Chomvilailuk, R. - Butcher, B. (2013): The effect of CSR knowledge on customer liking, across cultures. International Journal of Bank Marketing, 31(2): 98-114. https://doi.org/ $10.1108 / 02652321311298672$

Das, S. - Dixon, R. - Michael, A. (2015): Corporate social responsibility reporting: a longitudinal study of listed banking companies in Bangladesh. World review of business research., 5(1): 130-154.

Deckop, J. - Merriman, K. - Gupta, S. (2006): The effects of CEO pay structure on corporate social performance. Journal of Management, 32(3): 329-342. https://doi.org/ $10.1177 / 0149206305280113$

Deutsch, N. (2011): A technológiai rendszerek innovációja. Az elosztott villamosenergiatermelési technológiák fenntarthatósági értékelése és rendszerinnovációs potenciáljának vizsgálata az Európai Unióban (Innovation of technological systems. The sustainability assessment of distributed energy generation technologies and the examination of their system innovation potential in the European Union). PhD dissertation, Manuscript.

Fatma, M. - Rahman, Z. - Khan, I. (2014): Multi-Item Stakeholder Based Scale to Measure CSR in the Banking Industry. International Strategic Management Review, 2(1): 9-20. https://doi.org/10.1016/j.ism.2014.06.001

Flavian, C. - Guinaliu, M. - Torres, E. (2005). The influence of corporate image on consumer trust: a comparative analysis in traditional versus internet banking. Internet Research, 15(4): 447-470. https://doi.org/10.1108/10662240510615191

Greening, D.W. - Turban, D.B. (2000): Corporate social performance as a competitive advantage in attracting a quality workforce. Business \& Society, 39(3): 254-280. 
Griffin, J. - Mahon, J. (1997): The corporate social performance and corporate financial performance debate. Twenty-five years of incomparable research. Business and Society, 36(1): 5-31. https://doi.org/10.1177/000765039703600102

Griffin, J.J. (2000): Corporate social performance: Research directions for the 21st century. Business and Society, 39(4): 479-491. https://doi.org/10.1177/000765030003900407

Härle, P. - Lüders, E. - Pepanides, T. - Pfetsch, S. - Poppensieker, T. - Stegemann, U. (2010): Basel III and European banking: Its impact, how banks might respond, and the challenges of implementation. McKinsey Working Papers on Risk, Number 26.

Islam, K.Z. (2012). Corporate Social Responsibility (CSR) and Issue to Corporate Financial Performance (CFP): An Empirical Evidence on Dhaka Stock Exchange (DSE) Listed Banking Companies in Bangladesh. European Journal of Business and Management, 4(11): 18-26.

Jo, H. - Kim, H. - Park, K. (2014). Corporate environmental responsibility and firm performance in the financial services sector. Journal of Business Ethics, 131(2): 1-28. https://doi.org/10.1007/s10551-014-2276-7

Joyner, B.E. - Payne, D. (2002): Evolution and implementation: A study of values, business ethics and corporate social responsibility. Journal of Business Ethics, 41(4): 297-311. https://doi.org/10.1023/A:1021237420663

Kotler, P. - Lee, N. (2004): Corporate social responsibility: Doing the most good for your company and your cause. John Wiley \& Sons.

Laidroo, L. - Sokolova, M. (2015): International banks' CSR disclosures after the 2008 crisis. Baltic Journal of Management, 10(3): 270-294. https://doi.org/10.1108/BJM-08-20140128

Lee, D.D. - Faff, R.W. - Langfield-Smith, K. (2009): Revisiting the vexing question: does superior corporate social performance lead to improved financial performance? Australian Journal of Management, 34(1): 21-49. https://doi.org/10.1177/031289620903400103

Lentner, Cs. - Kolozsi, P. - Tóth, G. (2010): A pénzügyi válságkezelés új útjai (New ways of financial crisis management). EU Working Papers, 1/2010: 3-18.

Lentner, Cs. - Szegedi, K. - Tatay, T. (2015): Társadalmi felelösségvállalás a bankszektorban (Social responsibility in the banking sector). Pénzügyi Szemle, 60(1): 96-104.

Lu, W. - Chau, K.W. - Wang, H. - Pan, W. (2014): A decade's debate on the nexus between corporate social and corporate financial performance: a critical review of empirical studies 2002-2011. Journal of Cleaner Production, 79 (September): 195-206. https://doi.org/10.1016/j.jclepro.2014.04.072 
Malik, M.S. - Nadeem, M. (2014): Impact of corporate social responsibility on the financial performance of banks in Pakistan. International Letters of Social and Humanistic Sciences, 10(1): 9-19. https://doi.org/10.18052/www.scipress.com/ILSHS.21.9

Mallin, C. - Farag, H. - Ow-Yong, K. (2014): Corporate social responsibility and financial performance in Islamic banks. Journal of Economic Behavior \& Organization, 103 (Supplement, July): S21-S38. https://doi.org/10.1016/j.jebo.2014.03.001

Marcia, M.C. - Otgontsetseg, E. - Hassan, T. (2013): Corporate Social Responsibility and its Impact on Financial Performance: Investigation of US Commercial Banks. Unpublished research paper, Department of Finance, Bentley University, Waltham, US.

Marom, I.Y. (2006): Toward a unified theory of the CSP-CFP link. Journal of Business Ethics, 67(2): 191-200. https://doi.org/10.1007/s10551-006-9023-7

McDonald, L.M. - Hung Lai, C. (2011): Impact of corporate social responsibility initiatives on Taiwanese banking customers. International Journal of Bank Marketing, 29(1): 50-63. https://doi.org/10.1108/02652321111101374

Mcllroy, D.H. (2008): Regulating risks: A measured response to the banking crisis. Journal of Banking Regulation, 9(4): 284-292. https://doi.org/10.1057/jbr.2008.15

Mohr, L.A. - Webb, D.J. - Harris, K.E. (2001): Do consumers expect companies to be socially responsible? The impact of corporate social responsibility on buying behavior. The Journal of Consumer Affairs, 35(1): 45-72. https://doi.org/10.1111/j.1745-6606.2001.tb00102.x

Mozghovyi, Y. - Ratnykova, I. (2011): Correlation between the Corporate Social Responsibility and Financial Performance of the Bank in Ukrainian Context. Corporate Ownership and Control, 8(2): 120-130. https://doi.org/10.22495/cocv8si2p6

Ofori, D.F. - Nyuur, R.B. - S-Darko, M.D. (2014): Corporate social responsibility and financial performance: fact or fiction? A look at Ghanaian banks: original research. Acta Commercii, 14(1): 1-11. https://doi.org/10.4102/ac.v14i1.180

Okwemba, E.M. - Mwalati, S.C. - Egessa, R. - Musiega, D. - Maniagi, G.M. (2014): Effect of Corporate Social Responsibility on Organisation Performance, Banking Industry Kenya, Kakamega County. International Journal of Business and Management Invention, 3 (4): 37-51.

Omoro, N. - Kinyua, H. - Okiro, K. (2014): Investment in Corporate Social Responsibility and Sustained Growth in Commercial Banks in Kenya, Journal of Emerging Issues in Economics. Finance and Banking, 3(2): 1047-1068.

Orlitzky, M. (2011): Institutional logics in the study of organizations: The social construction of the relationship between corporate social and financial performance. Business Ethics Quarterly, 21(03): 409-444. https://doi.org/10.5840/beq201121325 
Orlitzky, M. - Schmidt, F.L. - Rynes, S.L. (2003): Corporate social and financial performance: A meta-analysis. Organization Studies, 24(3): 403-441. https://doi.org/ $10.1177 / 0170840603024003910$

Pérez, A. - Martinez, P. - del Bosque, R. (2013): The development of a stakeholder-based scale for measuring corporate social responsibility in the banking industry. Service Business, 7(3): 459-481. https://doi.org/10.1007/s11628-012-0171-9

Porter, M. - Kramer, M. (2011): The big idea - creating shared value - How to reinvent capitalism - and unleash a wave of innovation and growth. Harvard Business Review, 89 (1-2): 62-77.

Rádóczy, K. (2017): Passziv és aktiv befektetési formák: Carhart-modell alkalmazhatósága öngondoskodás esetén. Várakozások és gazdasági interakciók (Passive and active forms of investment: The applicability of the Carhart model in the case of self-provision. Expectations and economic interactions), Szegedi Tudományegyetem, JATE Press, pp. 141-156.

Rappaport, A. (2006): Ten ways to create shareholder value. Harvard Business Review, 84(9): 66-77.

Raihan, M.Z. - Bakar, R. - Islam, M.A. (2015): Impact of Corporate Social Responsibility (CSR) Expenditures on Financial Performance of Islami Bank Bangladesh Ltd. The Social Sciences, 10(2): 171-177.

Relano, F. - Paulet, E. (2012): Corporate responsibility in the banking sector: a proposed typology for the German case. International Journal of Law and Management, 54(5): 379-393. https://doi.org/10.1108/17542431211264269

Rogošić, A. (2014): Corporate social responsibility reporting of the banks in Bosnia and Herzegovina, Croatia and Montenegro. Theoretical and Applied Economics, 21(9): 71-82.

Ruf, B.M. - Muralidhar, K. - Brown, R M. - Janney, J.J. - Paul, K. (2001): An empirical investigation of the relationship between change in corporate social performance and financial performance: A stakeholder theory perspective. Journal of Business Ethics, 32(2): 143-156. https://doi.org/10.1023/A:1010786912118

Schaltegger, S. - Lüdeke-Freund, F. - Hansen, E.G. (2012): Business cases for sustainability: the role of business model innovation for corporate sustainability. International Journal of Innovation and Sustainable Development, 6(2): 95-119. https://doi.org/10.1504/ IJISD.2012.046944

Scholtens, B. (2008): Corporate Social Responsibility in the International Banking Industry. Business Ethics, 86(2): 159-175. https://doi.org/10.1007/s10551-008-9841-x 
Schreck, P. (2011): Reviewing the Business Case for Corporate Social Responsibility: New Evidence and Analysis. Journal of Business Ethics, 103(2): 167-188. https://doi.org/ 10.1007/s10551-011-0867-0

Sen, S. - Bhattacharya, C.B. (2001): Does doing good always lead to doing better? Consumer reactions to corporate social responsibility. Journal of marketing Research, 38(2): 225-243. https://doi.org/10.1509/jmkr.38.2.225.18838

Simpson, W.G. - Kohers, T. (2002): The Link Between Corporate Social and Financial Performance: Evidence from the Banking Industry. Journal of Business Ethics, 35(2): 97109. https://doi.org/10.1023/A:1013082525900

Soana, M.G. (2011): The Relationship Between Corporate Social Performance and Corporate Financial Performance in the Banking Sector. Journal of Business Ethics, 104(1): 133-148. https://doi.org/10.1007/s10551-011-0894-x

Tran, Y.T.H. (2014): CSR in Banking Sector: A Literature Review and New Research Directions. International Journal of Economics, Commerce and Management, II(11).

Truscott, R.A. - Bartlett, J.L. - Tywoniak, S.A. (2009): The reputation of the corporate social responsibility industry in Australia. Australasian Marketing Journal, 17(2): 84-91. https://doi.org/10.1016/j.ausmj.2009.05.001

Tschopp, D. (2012): Drivers of corporate social responsibility reporting; Case studies from three reporting companies. International Journal of Business and Social Research, 2(2): $1-11$.

Saxena, M. - Kohli, A.S. (2012): Impact of Corporate Social Responsibility on Corporate Sustainability: A Study of the Indian Banking Industry. The IUP Journal of Corporate Governance, 11(4): 39-54.

Vigano, F. - Nicolai, D. (2009): CSR in the European banking sector: evidence from a survey. In: Corporate Social Responsibility in Europe: Rhetoric and Realities. Edward Elgar Publishing.

Waddock, S.A. - Graves, S.B. (1997): The corporate social performance-financial performance link. Strategic Management Journal, 18(4): 303-319. https://doi.org/10.1002/(SICI)10970266(199704)18:4<303::AID-SMJ869>3.0.CO;2-G

Wu, M.W. - Shen, C.H. (2013): Corporate social responsibility in the banking industry: Motives and financial performance. Journal of Banking \& Finance, 37(9): 3529-3547. https://doi.org/ 10.1016/j.jbankfin.2013.04.023

Yeung, S. (2011): The role of banks in corporate social responsibility. Journal of Applied Economics and Business Research, 1(2): 103-115. 